\title{
Assessment of Climate Change Effects on Water Resources in the Yellow River Basin, China
}

\author{
Zhiyong Wu, ${ }^{1,2}$ Heng Xiao, ${ }^{2}$ Guihua Lu, ${ }^{1}$ and Jinming Chen ${ }^{2}$ \\ ${ }^{1}$ National Engineering Research Center of Water Resources Efficient Utilization and Engineering Safety, Hohai University, \\ Nanjing 210098, China \\ ${ }^{2}$ College of Hydrology and Water Resource, Hohai University, Nanjing 210098, China
}

Correspondence should be addressed to Zhiyong Wu; wzyhhu@gmail.com

Received 23 April 2014; Revised 30 August 2014; Accepted 31 August 2014

Academic Editor: Huiwang Gao

Copyright $\odot 2015$ Zhiyong Wu et al. This is an open access article distributed under the Creative Commons Attribution License, which permits unrestricted use, distribution, and reproduction in any medium, provided the original work is properly cited.

\begin{abstract}
The water resources in the Yellow River basin (YRB) are vital to social and economic development in North and Northwest China. The basin has a marked continental monsoon climate and its water resources are especially vulnerable to climate change. Projected runoff in the basin for the period from 2001 to 2030 was simulated using the variable infiltration capacity (VIC) macroscale hydrology model. VIC was first calibrated using observations and then was driven by the precipitation and temperature projected by the RegCM3 high-resolution regional climate model under the IPCC scenario A2. Results show that, under the scenario A2, the mean annual temperature of the basin could increase by $1.6^{\circ} \mathrm{C}$, while mean annual precipitation could decrease by $2.6 \%$. There could be an $11.6 \%$ reduction in annual runoff in the basin according to the VIC projection. However, there are marked regional variations in these climate change impacts. Reductions of 13.6\%, 25.7\%, and 24.6\% could be expected in the regions of Hekouzhen to Longmen, Longmen to Sanmenxia, and Sanmenxia to Huayuankou, respectively. Our study suggests that the condition of water resources in the YRB could become more severe in the period from 2001 to 2030 under the scenario A2.
\end{abstract}

\section{Introduction}

Observational records and climate projections provide abundant evidence that freshwater resources are vulnerable and have the potential to be strongly impacted by climate change [1]. Changes in the hydrological cycle caused by climate change may likely affect runoff, flood intensity and frequency, and intensity and duration of low flow $[2,3]$. These changes in the hydrological cycle may result in further impacts on the water resource management and socioeconomic systems $[4,5]$.

The Yellow River basin (YRB) is located in semiarid to arid climate zones and is an important water resource supply in North China. The mean annual natural runoff volume of 58 billion $\mathrm{m}^{3}$ only makes up $2 \%$ of the total river runoff in China. Mean annual runoff is $77 \mathrm{~mm}$, equating to $28 \%$ of the national average of China. Arable land per mu of water, which is $324 \mathrm{~m}^{3}$, accounts for only $18 \%$ of the national arable land per mu of water of China.
The water resource utilization rate reaches up to $84 \%$, and the net water consumption rate is $53 \%$. Particularly in the past two decades, with global warming and heightened human activities, runoff has decreased significantly, which may lead to greater conflict between water supply and demand. Water shortage is considered the future sustainable development bottleneck of the YRB [6,7]. Thus, the analysis of climate change impacts on runoff is of great importance for the utilization and management of water resources in the YRB.

The global climate model (GCM) is one of the best tools available for assessing future climate change caused by greenhouse gas emissions. Currently, many achievements have been made in the assessment of effects of climate change on water resources using output of GCMs in the YRB $[6,8-$ 12]. Although GCMs can simulate the characteristics of largescale atmospheric circulation, there are significant gaps in forecasting climate change on regional scales [10]. Developing regional climate models (RCMs) with high spatial 
and temporal resolution, the ability to capture variability of small-scale systems and better simulations of climate features caused by local forcing has become an important goal in regional climate research. Resently, using the RCMs output for hydrological impact studies could be found in Cloke et al. [13], Fiseha et al. [14], and Smith et al. [15]. However, due to the limitations in computer capability, only a few simulation experiments by RCMs have been done in China $[16,17]$.

The objective of this paper is to assess the impacts of climate change on runoff in the YRB by coupling RegCM3 highresolution regional climate model with the VIC hydrological model. Impacts of future climate change on runoff in the YRB are analyzed and these could provide a scientific basis for water resources management.

\section{Data and Methodology}

2.1. $\operatorname{Reg} C M 3$. RegCM3 is a high-resolution regional climate model. It is nested in one-way mode with the NASA/NCAR finite volume element AGCM (FvGCM), which was provided by the Abdus Salam International Center for Theoretical Physics, ICTP. The RegCM3 model does relatively well simulate the climate of East Asia and China and does especially well in the simulation of monsoon rainfall $[17,18]$.

The RegCM3 outputs for the baseline period (1971-2000) and a future period (2001-2030) with greenhouse gas forcing from the IPCC A2 scenario used in this study were provided by National Climate Center of China. The A2 emission scenario lies toward the high end of the IPCC range, with $\mathrm{CO}_{2}$ concentrations in the atmosphere of about $850 \mathrm{ppm}$ by 2100 [19]. Daily maximum and minimum temperature and precipitation were used in this study and the spatial resolutions of these variables were at $50 \mathrm{~km} \times 50 \mathrm{~km}$ (total 431 grid points).

Although the RegCM3 had validated model performance for the baseline period, there is certain systematic bias remaining in the YRB due to the RegCM3 model skill itself and the bias inherited from the driving GCM [20]. Compared with observations, the simulated mean annual temperature and mean annual precipitation are $1.0^{\circ} \mathrm{C}$ lower and $216.2 \mathrm{~mm}$ higher, respectively. As shown in Figure 1(a), RegCM3 overestimated the precipitation over the YRB, especially in the upper Yellow River basin with the errors more than $0.8 \mathrm{~mm} / \mathrm{d}$. However, RegCM3 showed a substantial improvement in simulating the distribution in the middle and downstream Yellow River basin by comparing with GCM (NCAR) simulation (Figure 1(b)).

2.2. Correction of the RegCM3 Output. To eliminate the systematic bias in the RegCM3 output, bias corrections were carried out by the same-multiple method for each grid. First, the mean annual values of the observed $\left(\overline{x_{\mathrm{obs}, i}}\right)$ and simulated $\left(\overline{x_{\text {RegCM } 3, i}}\right)$ data from 1971 to 2000 were calculated. Second, the revised coefficient $\left(\lambda_{\text {RegCM } 3, i}\right)$ was calculated using (1).
TABLE 1: Seven VIC user calibrated hydrological parameters.

\begin{tabular}{|c|c|}
\hline $\begin{array}{l}\text { Parameter } \\
\text { description }\end{array}$ & Parameter description \\
\hline$b \_$infilt & Variable infiltration curve \\
\hline Dsmax & Maximum velocity of baseflow \\
\hline Ds & $\begin{array}{l}\text { Fraction of Dsmax where nonlinear baseflow } \\
\text { begins }\end{array}$ \\
\hline Ws & $\begin{array}{l}\text { Fraction of maximum soil moisture where } \\
\text { nonlinear baseflow occurs }\end{array}$ \\
\hline$d 0$ & Thickness of first soil moisture layer \\
\hline$d 1$ & Thickness of second soil moisture layer \\
\hline$d 2$ & Thickness of third soil moisture layer \\
\hline
\end{tabular}

Finally, using (2), the modified data series $\chi_{\text {RegCM3revised, } i}$ was calculated by multiplying the values from RegCM3 by the revised coefficient $\left(\lambda_{\mathrm{RegCM} 3, i}\right)$. Consider

$$
\begin{gathered}
\lambda_{\mathrm{RegCM} 3, i}=\frac{\overline{x_{\mathrm{obs}, i}}}{\overline{x_{\mathrm{RegCM} 3, i}}}, \\
x_{\text {RegCM3revised }, i}=\lambda_{\operatorname{RegCM} 3, i} \times x_{\operatorname{RegCM} 3, i} .
\end{gathered}
$$

Temperature was revised using the difference value method. The revised temperature value $\left(T_{\text {RegCM3revised, } i}\right)$ was calculated as the difference between the mean annual temperature $\left(\Delta_{\mathrm{RegCM} 3, i}\right)$ plus the temperature value of the RegCM3 $\left(T_{\text {RegCM } 3, i}\right)$. Consider

$$
\begin{aligned}
\Delta_{\mathrm{RegCM} 3, i} & =\overline{T_{\mathrm{obs}, i}}-\overline{T_{\mathrm{RegCM} 3, i}}, \\
T_{\mathrm{RegCM} 3 \text { revised }, i} & =T_{\mathrm{RegCM} 3, i}+\Delta_{\mathrm{RegCM} 3, i}
\end{aligned}
$$

2.3. VIC Model. The variable infiltration capacity (VIC) distributed hydrological model is a macroscale hydrological model based on a soil-vegetation-atmosphere transfer scheme (SVATS), which was designed to describe the land surface in numerical weather prediction and climate and describe the variation and transfer of water and energy. It has been widely used for climate change impact studies [21, 22]. The basic principles of the VIC model are described in Liang et al. [23].

A model for assessing the effects of climate change on the YRB was established at a $50 \mathrm{~km} \times 50 \mathrm{~km}$ resolution based on the VIC model. For each grid point, the forcing data were generated using the inverse distance weighted method based on 126 meteorological stations with daily precipitation and maximum and minimum temperature. These observations are obtained from the China Meteorological Data Sharing Service System (http://cdc.cma.gov.cn/index.jsp). Soil and vegetation parameters were determined according to the global soil database at $10 \mathrm{~km}$ resolution and the global land vegetation cover database at $1 \mathrm{~km}$ resolution $[24,25]$.

Seven VIC hydrological parameters (Table 1) were required for calibrations. The procedure of VIC calibration was similar to that of $\mathrm{Wu}$ et al. [26]. Ten typical subbasins (Figure 2) were selected according to the geographical position, land boundary conditions, and climate characteristics 


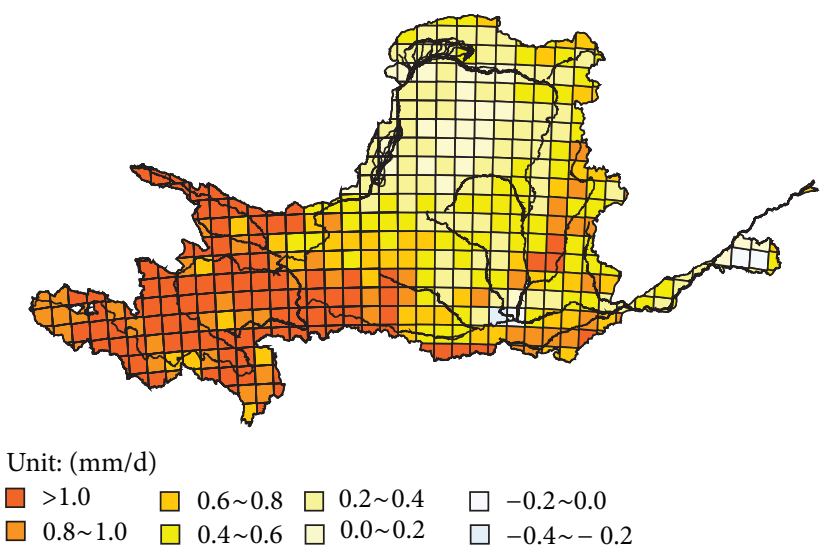

(a)

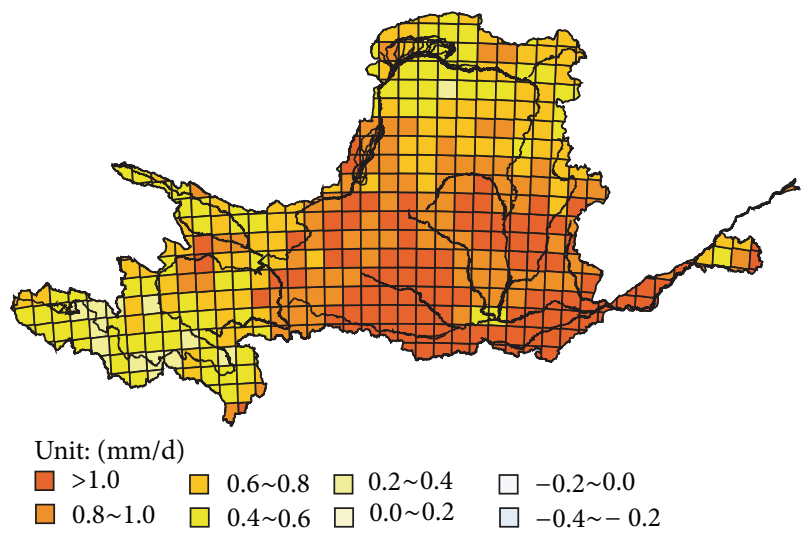

(b)

FIGURE 1: The geographical distributions of bias for precipitation (units: $\mathrm{mm} / \mathrm{d}$ ) between (a) RegCM3 and (b) NCAR and observations, respectively, in the period of $1971-2000$.

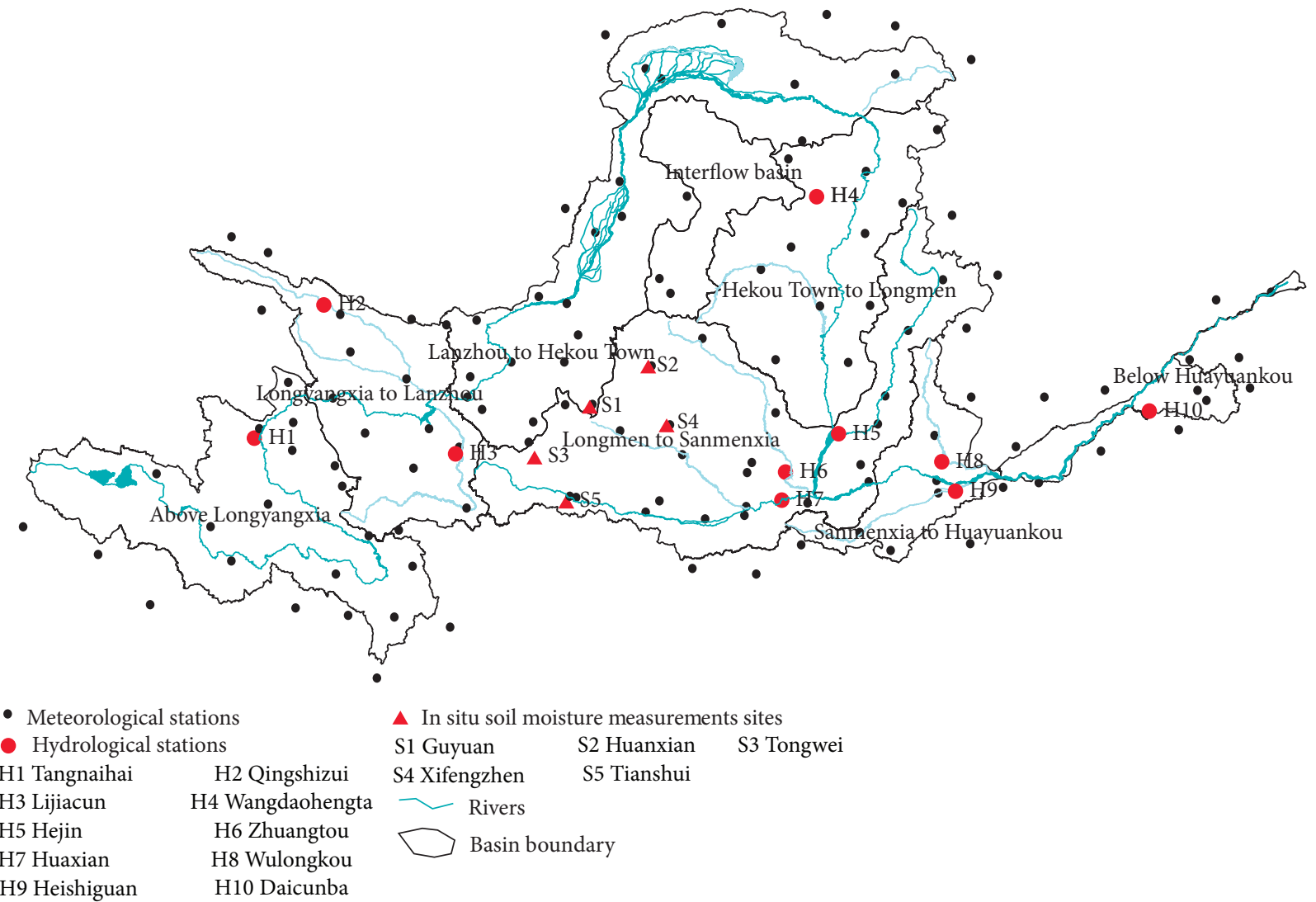

FIGURE 2: The geographic distribution of the 10 subbasins in the YRB.

of the YRB. These subbasins captured all of the features of the climate and land boundary conditions in the YRB. We kept the thickness of the first soil moisture layer constant $(d 0$ $=0.1 \mathrm{~m}$ ) and used observed daily hydrographs to calibrate the remaining six parameters.

Hydrological parameters of 288 grid cells (accounting for $67 \%$ of the total grid cells) could be calibrated by the observed discharge data in the selected subbasins. Parameters of the remaining grid cells were extrapolated assuming hydrologic similarity. The detailed steps were as follows. (1) Parameters were regionalized based on climate and soil divisions. (2) Within the same division, the average values of the hydrological parameters of all the calibrated grid cells were transplanted to the remaining grid cells. However, if a division did not contain a whole watershed, the division value was transplanted from nearby parameter values. 


\section{Results}

3.1. VIC Model Calibration and Validation. With the NashSutcliffe efficiency coefficient $\left(R^{2}\right)$ and relative error $(\mathrm{Re})$ acting as the objective functions, the VIC model hydrological parameters were calibrated (Tables 2 and 3). Results show that the relative error ranged from $-13.3 \%$ to $24.6 \%$, the daily discharge process efficiency coefficient ranged from 0.43 to 0.82 , and the mean value is 0.63 . The maximum and minimum monthly discharge process efficiency coefficients are 0.89 and 0.64 , respectively, and the mean value is 0.81 . We also obtained in situ soil moisture measurements from 5 sites ([24]; Figure 2) for model validation. Figure 3 shows the simulated and observed soil moisture for Xifengzhen (site S4 in Figure 2) located in a semihumid region. The correlation coefficient of simulated and observed soil moisture $(r)$ is 0.82 for depths of $0-100 \mathrm{~cm}$, indicating satisfactory model performance. Thus, the established assessment model based on the VIC model is applicable for studying the impacts of climate change in the YRB.

3.2. Analysis of the Baseline Simulated Flow. A comparison was made of runoff simulated using bias-corrected RegCM3 data for the baseline period from 1971 to 2000 and runoff simulated using the 1971 to 2000 observed data. The results are shown in Figure 4. Compared with the mean annual runoff simulated by the VIC model, which was driven by the observations, the reduction of the runoff simulated by the bias-corrected RegCM3 data is $5.9 \%$. However, the spatial distribution of variation is nonuniform. This may have resulted from the daily process of the RegCM3 data. Precipitation days are counted according to the precipitation grade. The results show that, compared to observations, the precipitation days with mean annual precipitation of 0.1$1 \mathrm{~mm}$ and $1-10 \mathrm{~mm}$ are increased by $14 \mathrm{~d}$ and $13 \mathrm{~d}$, respectively, while the precipitation days of $10-20 \mathrm{~mm}$ and $20-50 \mathrm{~mm}$ are reduced by $1 \mathrm{~d}$. Runoff increased a little due to the increase in extreme precipitation events compared to the observations in some districts. These results suggest that the semidistributed VIC model that is established based on a physical mechanism can effectively simulate runoff in the YRB.

3.3. Runoff Trend Analysis. As shown in Table 4 and Figure 5, the projected temperature and precipitation would be increased by $1.6^{\circ} \mathrm{C}$ and decreased by $2.6 \%$ in the YRB, respectively. In the upper Yellow River basin (above Longyangxia and Longyangxia to Lanzhou), the temperature increases slower $\left(1.4^{\circ} \mathrm{C}\right)$ than that in the other subbasins and the precipitation is also increased by $6.2 \%$ and $1.7 \%$, respectively, with an opposite trend to them.

The projected changes in temperature and precipitation would potentially impact the hydrological regime in the YRB. The mean annual runoff is reduced by $1.4 \%$ to $25.7 \%$ with a mean reduction of $11.6 \%$ over the entire YRB. Generally, the change in runoff is consistent with the variation of precipitation. However, the mean annual runoff is still reduced by $1.4 \%$ and $6.2 \%$, respectively, in the upper Yellow River basin. One important reason is that the increased temperature

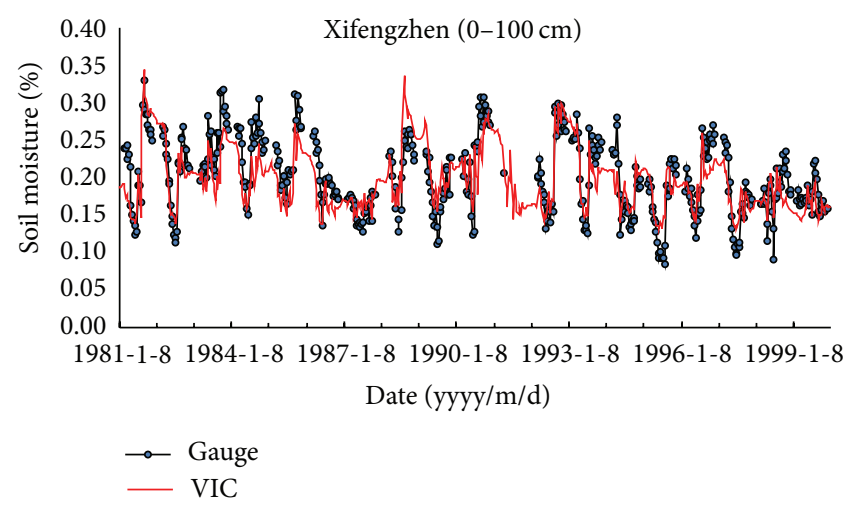

FIGURE 3: Comparison of simulated and observed soil moisture for depths of $0-100 \mathrm{~cm}$ at the Xifengzhen station.
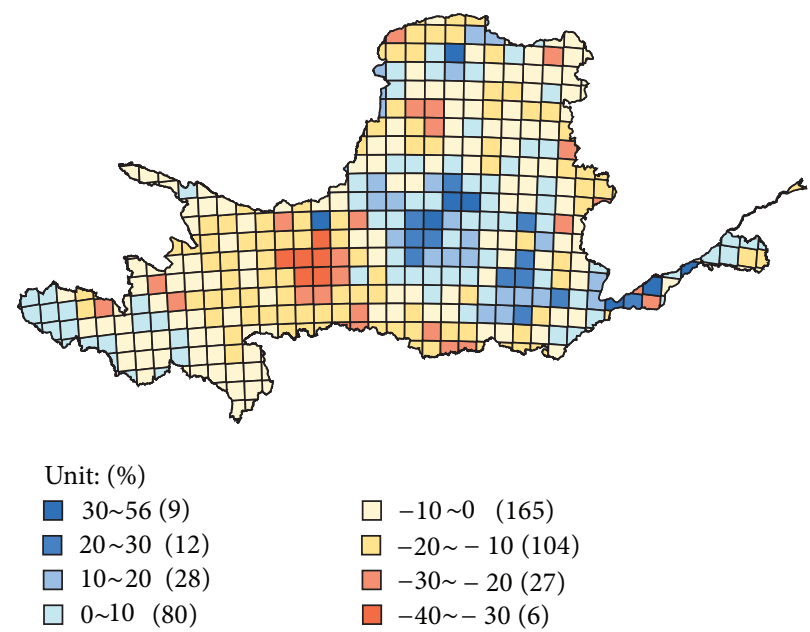

FIgURE 4: Variation in mean annual runoff simulated by biascorrected RegCM3 data compared to that simulated by the observed data (1971-2000).

leads to the increase of $14.0 \%$ and $7.1 \%$, respectively, in evapotranspiration and thus bringing out the reduction in runoff. Other researches also indicate that in the upper Yellow River basin temperature could have important impact on runoff $[27,28]$. The runoff reduction is relatively larger in the region of Longmen to Sanmenxia and Sanmenxia to Huayuankou with the reductions of $25.7 \%$ and $24.6 \%$, respectively.

At the monthly time scale (Table 5), there would be a decrease in the mean monthly runoff throughout the year with an exception for the months of January and February. The largest reduction of runoff (17.8\%) is likely to occur in August with the largest reduction in soil moisture. In autumn (September-October-November), due to an increase in evaporation $(9.4 \%, 13.8 \%$, and $15.3 \%)$ and a decrease in soil moisture $(5.1 \%, 3.4 \%$, and $4.1 \%)$, even with $9.7 \%, 7.3 \%$, and $2.8 \%$ increasing in precipitation, the corresponding monthly runoff could still be decreased by $7.6 \%, 11.3 \%$, and $15.4 \%$. 
TABLE 2: Values of six calibrated hydrological parameters.

\begin{tabular}{|c|c|c|c|c|c|c|c|}
\hline & Station & $B$ & Ds & Dsmax & Ws & $d 1$ & $d 2$ \\
\hline $\mathrm{H} 1$ & Tangnaihai & 0.23 & 0.0080 & 22.0 & 0.4 & 0.11 & 0.51 \\
\hline $\mathrm{H} 2$ & Qingshizui & 0.27 & 0.0230 & 16.0 & 0.9 & 0.36 & 0.98 \\
\hline $\mathrm{H} 3$ & Lijiacun & 0.08 & 0.0100 & 30.0 & 0.8 & 0.51 & 0.48 \\
\hline $\mathrm{H} 4$ & Wangdaohengta & 0.27 & 0.0280 & 5.0 & 0.9 & 0.58 & 1.47 \\
\hline H5 & Hejin & 0.02 & 0.0020 & 9.0 & 1.0 & 0.82 & 0.78 \\
\hline H6 & Zhuangtou & 0.06 & 0.0730 & 3.5 & 1.0 & 0.98 & 0.70 \\
\hline $\mathrm{H} 7$ & Huaxian & 0.15 & 0.0100 & 20.0 & 1.0 & 0.62 & 0.32 \\
\hline $\mathrm{H} 8$ & Wulongkou & 0.09 & 0.0020 & 29.7 & 0.4 & 0.52 & 0.46 \\
\hline $\mathrm{H} 9$ & Heishiguan & 0.14 & 0.0120 & 30.0 & 1.0 & 0.51 & 0.21 \\
\hline H10 & Daicunba & 0.09 & 0.0014 & 29.6 & 0.9 & 0.82 & 0.98 \\
\hline
\end{tabular}

TABLE 3: Calibration results of the VIC model in the 10 subbasins of the YRB.

\begin{tabular}{|c|c|c|c|c|c|c|c|c|c|}
\hline & Station & $\begin{array}{l}\text { Lon. } \\
\left({ }^{\circ} \mathrm{E}\right)\end{array}$ & $\begin{array}{l}\text { Lat. } \\
\left({ }^{\circ} \mathrm{N}\right)\end{array}$ & River & $\begin{array}{c}\text { Area } \\
\left(\mathrm{km}^{2}\right)\end{array}$ & $\begin{array}{l}\text { Period } \\
\text { (a) }\end{array}$ & $\begin{array}{l}\mathrm{Re} \\
(\%)\end{array}$ & $R_{D}^{2}$ & $R_{M}^{2}$ \\
\hline $\mathrm{H} 1$ & Tangnaihai & 100.150 & 35.500 & Yellow River & 121,972 & $1956-2007$ & 2.1 & 0.82 & 0.89 \\
\hline $\mathrm{H} 2$ & Qingshizui & 101.417 & 37.467 & Huangshui & 8,011 & $2000-2008$ & 8.0 & 0.61 & 0.77 \\
\hline $\mathrm{H} 3$ & Lijiacun & 103.817 & 35.267 & Tahoe & 19,693 & $1997-2007$ & 0.0 & 0.73 & 0.85 \\
\hline $\mathrm{H} 4$ & Wangdaohengta & 110.400 & 39.067 & Kuyiehe & 3,839 & 1980-1997 & -13.3 & 0.54 & 0.64 \\
\hline H5 & Hejin & 109.833 & 35.000 & Beiluohe & 25,645 & 1980-1990 & 15.8 & 0.45 & 0.67 \\
\hline H6 & Zhuangtou & 112.933 & 34.717 & Yiluohe & 18,563 & 1980-1996 & 15.2 & 0.43 & 0.86 \\
\hline $\mathrm{H} 7$ & Huaxian & 109.767 & 34.583 & Weihe & 106,498 & 1980-1997 & 5.5 & 0.66 & 0.88 \\
\hline $\mathrm{H} 8$ & Wulongkou & 112.683 & 35.150 & Qinhe & 9,245 & 1980-1997 & 9.7 & 0.74 & 0.88 \\
\hline $\mathrm{H} 9$ & Heishiguan & 110.717 & 36.467 & Yellow River & 3,992 & 1980-1997 & -0.7 & 0.70 & 0.86 \\
\hline $\mathrm{H} 10$ & Daicunba & 116.467 & 35.900 & Dawenhe & 8,264 & $1980-2000$ & 24.6 & 0.57 & 0.82 \\
\hline
\end{tabular}

TABle 4: Projected changes in mean annual temperature $(T)$, precipitation $(P)$, evapotranspiration $(E)$, runoff $(R)$, and soil moisture $(\mathrm{SM})$.

\begin{tabular}{lccccc}
\hline Subbasins & $T\left({ }^{\circ} \mathrm{C}\right)$ & $P(\%)$ & $E(\%)$ & $R(\%)$ & -1.4 \\
\hline Above Longyangxia & 1.4 & 6.2 & 14.0 & -6.2 & -0.4 \\
Longyangxia to Lanzhou & 1.4 & 1.7 & -3.1 & -3.1 & -1.9 \\
Lanzhou to Hekouzhen & 1.7 & -6.9 & -6.2 & -13.6 & -25.7 \\
Hekouzhen to Longmen & 1.8 & -5.6 & -4.9 & -2.1 & -6.6 \\
Longmen to Sanmenxia & 1.7 & -2.6 & 0.0 & -8.0 & -7.4 \\
Sanmenxia to Huayuankou & 1.6 & -4.8 & -2.5 & -8.0 & -2.9 \\
Below Huayuankou & 1.6 & -2.6 & 1.0 & -1.6 & -2.7 \\
Interflow basin & 1.8 & & &
\end{tabular}

TABle 5: Projected inner-annual changes in temperature $(T)$, precipitation $(P)$, evapotranspiration $(E)$, runoff $(R)$, and soil moisture $(\mathrm{SM})$.

\begin{tabular}{lcccccccccccc}
\hline & Jan. & Feb. & Mar. & Apr. & May & June & July & Aug. & Sept. & Oct. & Nov. & Dec. \\
\hline$T\left({ }^{\circ} \mathrm{C}\right)$ & 1.8 & 1.2 & 1.2 & 1.7 & 1.9 & 1.7 & 1.6 & 1.9 & 1.6 & 1.5 & 1.6 & 1.8 \\
$P(\%)$ & 15.6 & 16.7 & -12.4 & -2.6 & -13.9 & -2.9 & -4.3 & -8.5 & 9.7 & 7.3 & 2.8 & -4.0 \\
$E(\%)$ & 13.7 & 6.6 & 6.6 & 0.5 & -7.6 & -4.9 & 2.9 & -2.9 & 9.4 & 13.8 & 15.3 & 0.4 \\
$R(\%)$ & 5.1 & 2.4 & -13.4 & -9.5 & -14.2 & -8.4 & -5.4 & -17.8 & -7.6 & -11.3 & -15.4 & -11.3 \\
SM (\%) & -2.7 & -2.4 & -3.0 & -4.0 & -4.1 & -3.8 & -3.0 & -5.6 & -5.1 & -3.4 & -4.1 & -4.2 \\
\hline
\end{tabular}




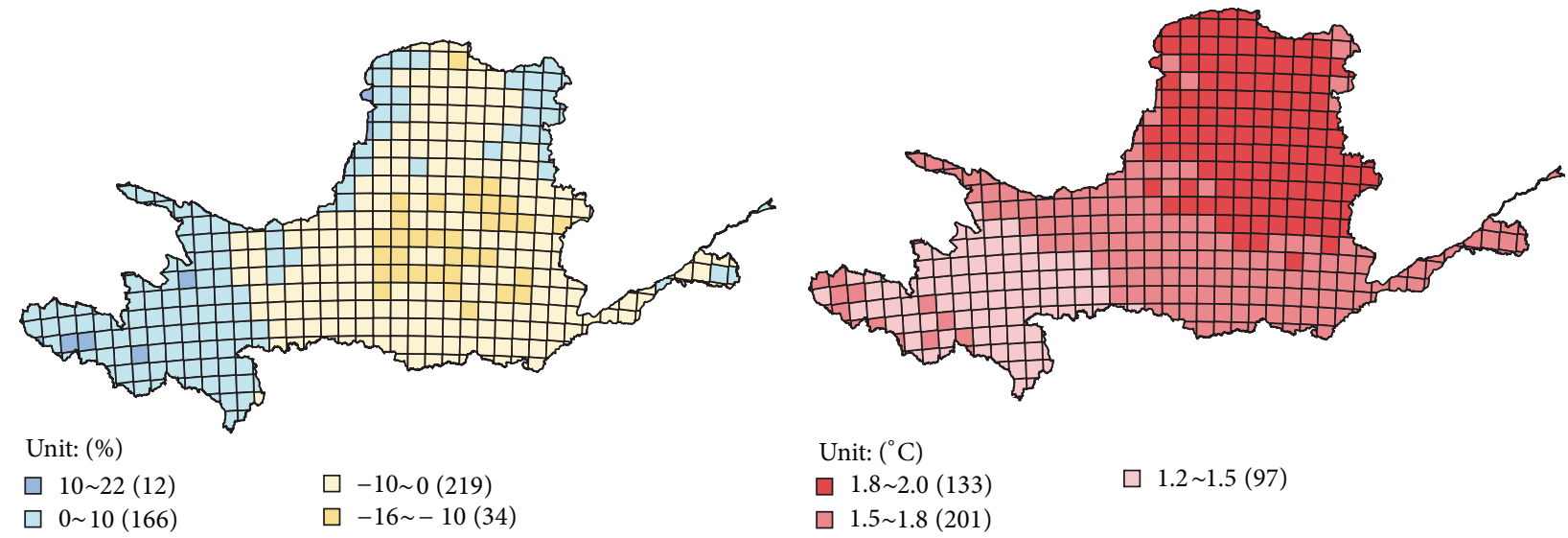

(a) Precipitation

(b) Temperature

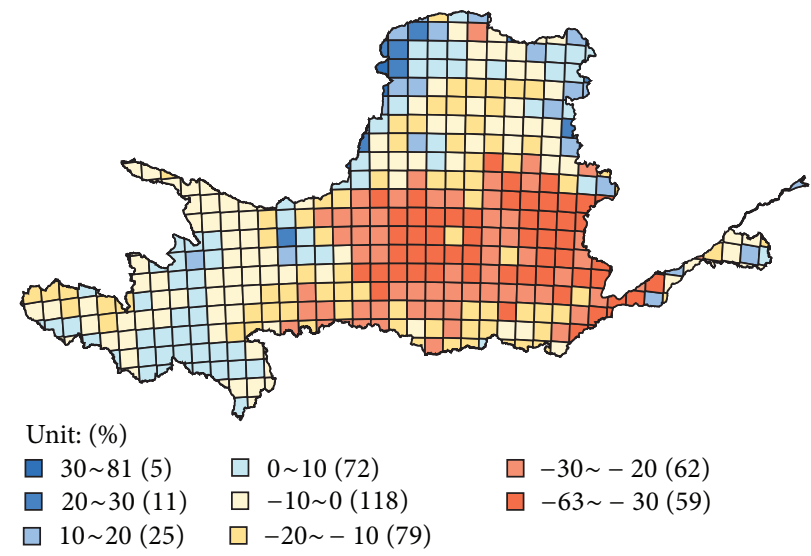

(c) Runoff

FIGURE 5: Changes in (a) mean annual precipitation, (b) mean annual temperature, and (c) mean annual runoff from the bias-corrected RegCM3 compared to that simulated by the baseline period (1971-2000) in the YRB.

\section{Discussion}

The primary aim of this study is to assess the impacts of climate change on runoff in the YRB by coupling RegCM3 with the VIC hydrological model. Hydrologic simulation is sensitive to biases in the means and spatial distributions of precipitation and temperature on monthly timescales [29]. In the RegCM3 model outputs, there were consistent biases in the simulation of mean rainfall and temperature for the YRB. To produce realistic runoff series when put into a hydrologic model, bias-correction is necessary to correct both the absolute magnitude of the precipitation and the seasonality of the observations, as has been noted by Hay et al. [30] and Wood et al. [29]. However, the bias-correction scheme used here is only for the mean monthly values of temperature and precipitation and does not correct the biases at the daily level. Using results of simple monthly mean climate corrections, the VIC model performs well in simulating runoff from 1971 to 2000 in the YRB, with the mean efficiency coefficient being 0.81 . Therefore, the samemultiple and the difference value methods, used for the biascorrection of all monthly data series, are preferred even though they resulted in some variability biases.
However, the results should be viewed with this uncertainty in mind as well as the uncertainty that still exists in the assessment of the effects of climate change on regional water resources. For example, Yu et al. [10] analyzed the mean annual runoff variation based on HadCM3, CSIRO_MKII, and CGCM1 models. The results showed that the mean annual runoff from 2010 to 2039 will change by $+2.7 \%$, $-1.3 \%$, and $-9.1 \%$, respectively, compared to that of 1961 to 1990. Wang et al. [9] projected the future runoff variation in the YRB, based on a monthly hydrological model, which indicated that runoff in the regions from upstream of Lanzhou, Hekouzhen to Longmen, Longmen to Sanmenxia, and Sanmenxia to Huayuankou would decrease by $18.7 \%$, $24.9 \%, 27.1 \%$, and $22.5 \%$, respectively, on the assumption that temperature will rise by $2.0^{\circ} \mathrm{C}$ and precipitation will decrease by $10 \%$. These results suggest that our results are consistent with the findings in previous studies.

\section{Conclusions}

The results of this investigation using RegCM3 data to assess the impacts of climate change on runoff in the YRB suggest 
that (1) in the future, the mean annual temperature could be increased by $1.6^{\circ} \mathrm{C}$, and the largest increase is found in the upper Yellow River basin. (2) Mean annual precipitation could be reduced by $2.6 \%$ in the YRB. However, mean annual precipitation in the regions from Longyangxia to Lanzhou and in the upper reaches of the Yellow River starting from Lanzhou may increase by $6.4 \%$ and $1.7 \%$, respectively. (3) Mean annual runoff will decrease by $11.6 \%$. Reductions in the regions from Longyangxia to Lanzhou and in the upper reaches of the Yellow River starting from Lanzhou may be relatively small, but changes in the regions from Hekou Town to Longmen, Longmen to Sanmenxia, and Sanmenxia to Huayuankou may be larger, with reductions of $13.6 \%, 25.7 \%$, and $24.6 \%$, respectively. Decreases in runoff may strengthen the conflict between water supply and demand and limit the sustainable socioeconomic development in the YRB.

\section{Conflict of Interests}

The authors declare that there is no conflict of interests regarding the publication of this paper.

\section{Acknowledgments}

This work is supported by Program for New Century Excellent Talents in University (Grant no. NCET-12-0842), Natural Science Foundation of Jiangsu Province of China (Grant no. BK20131368), and Qing Lan Project and Foundation for the Author of National Excellent Doctoral Dissertation of China (Grant no. 201161).

\section{References}

[1] C. Z. W. B. Bates, W. Z. Kundzewicz, S. Wu, and J. Palutikof, Climate Change and Water, IPCC Secretariat, Geneva, Switzerland, 2008.

[2] Y. Li, Y. Li, X. Li, and J. Xu, "Response of hydrological processes to land cover and climate changes in Songhuaba watershed, Southwest China," Disaster Advances, vol. 5, no. 1, pp. 68-76, 2012.

[3] Y. Chen, Y. Yin, X. Chen, and W. Xu, "Change and future pattern of provincial flood affected areas in China: possible relationship with climate change," Disaster Advances, vol. 5, no. 4, pp. 321326, 2012.

[4] G. H. Lu, H. Xiao, Z. Y. Wu, S. L. Zhang, and Y. Li, "Assessing the impacts of future climate change on hydrology in HuangHuai-Hai Region in China using the PRECIS and VIC Models," Journal of Hydrologic Engineering, vol. 18, no. 9, pp. 1077-1087, 2013.

[5] J. Zhang and G. Wang, Impacts Research of Climate Change on Hydrology and Water Resource, Science Press, Beijing, China, 2007, (Chinese).

[6] C. Liu and H. Zheng, "Trend analysis of hydrological components in the Yellow River basin," Journal of Natural Resources, vol. 18, no. 2, pp. 129-135, 2003.

[7] D. Pan and H. Jia, "Drought disaster risk assessment of the Yellow River Basin based on historical drought information in GIS environment," Disaster Advances, vol. 5, no. 4, pp. 90-94, 2012.
[8] Z. Hao, L. Li, L. Zhang et al., "Applicability of GCM in head region of Yellow River," Journal of Hohai University (Natural Sciences), vol. 1, pp. 7-11, 2009.

[9] G. Wang, Y. Wang, and C. Shang, Impact of Climate Change on Water Resource in the Yellow River. Yellow River, vol. 9, 2000, (Chinese).

[10] F. Yu, G. Zhang, and Y. Liu, "Analysis on effects of global climate change on water resource in the Yellow River basin," Journal of Hydrology, vol. 28, no. 5, pp. 52-56, 2008.

[11] G. Zhang, "Analysis on potential effects of global climate change on natural runoff in the Yellow River Basin," Geographical Research, vol. 25, no. 2, pp. 268-275, 2006.

[12] F. Zhao and $\mathrm{Z}$. Xu, "Comparative analysis on downscaled climate scenarios for headwater catchment of Yellow River using SDS and delta methods," Acta Meteorologica Sinica, vol. 4, pp. 653-662, 2007.

[13] H. L. Cloke, F. Wetterhall, Y. He, J. E. Freer, and F. Pappenberger, "Modelling climate impact on floods with ensemble climate projections," Quarterly Journal of the Royal Meteorological Society, vol. 139, no. 671, pp. 282-297, 2013.

[14] B. M. Fiseha, S. G. Setegn, A. M. Melesse, E. Volpi, and A. Fiori, "Impact of climate change on the hydrology of upper Tiber River basin using bias corrected regional climate model," Water Resources Management, vol. 28, no. 5, pp. 1327-1343, 2014.

[15] A. Smith, P. Bates, J. Freer, and F. Wetterhall, "Investigating the application of climate models in flood projection across the UK," Hydrological Processes, vol. 28, no. 5, pp. 2810-2823, 2014.

[16] Y. Xu and R. Jones, "Validating PRECIS with ECMWF reanalysis data over China," Chinese Journal of Agrometeorology, vol. 25, no. 1, pp. 5-9, 2004.

[17] X. J. Gao, Y. Shi, and F. Giorgi, "A high resolution simulation of climate change over China," Science China Earth Sciences, vol. 54, no. 3, pp. 462-472, 2011.

[18] D. Zhang, L. Ouyang, X. Gao et al., "Simulation of the atmospheric circulation over East Asia and climate in China by RegCM3," Journal of Tropical Meteorology, vol. 23, no. 5, pp. 444-452, 2007.

[19] N. Nakicenovic and R. Swart, Emissions Scenarios, IPCC Secretariat, Geneva, Switzerland, 2000.

[20] Y. Shi, Climate change in China as simulated by a high resolution regional climate model [M.S. thesis], Chinese Academy of Meteorological Science, 2007.

[21] J. Jin, G. Lu, and Z. Wu, "Application research of VIC model to arid and semi-arid Region of Northwest China," Water Resource and Power, no. 1, pp. 12-14, 2010.

[22] B. Nijssen, G. M. O'Donnell, D. P. Lettenmaier, D. Lohmann, and E. F. Wood, "Predicting the discharge of global rivers," Journal of Climate, vol. 14, no. 15, pp. 3307-3323, 2001.

[23] X. Liang, D. P. Lettenmaier, E. F. Wood, and S. J. Burges, "Simulations of the ENSO hydroclimate signals in the Pacific Northwest Columbia River Basin," Bulletin of the American Meteorological Society, vol. 80, no. 11, pp. 2313-2329, 1994.

[24] C. A. Reynolds, T. J. Jackson, and W. J. Rawls, "Estimating soil water-holding capacities by linking the Food and Agriculture Organization soil map of the world with global pedon databases and continuous pedotransfer functions," Water Resources Research, vol. 36, no. 12, pp. 3653-3662, 2000.

[25] M. C. Hansen, R. S. Defries, J. R. G. Townshend, and R. Sohlberg, "Global land cover classification at $1 \mathrm{~km}$ spatial resolution using a classification tree approach," International Journal of Remote Sensing, vol. 21, no. 6-7, pp. 1331-1364, 2000. 
[26] Z. Wu, G. Lu, L. Wen, C. A. Lin, J. Zhang, and Y. Yang, “Thirtyfive year (1971-2005) simulation of daily soil moisture using the variable infiltration capacity model over China," AtmosphereOcean, vol. 45, no. 1, pp. 37-45, 2007.

[27] W. Sun, B. Cheng, and R. Li, "Mutitime scale correlation between runoff and regional climate variation in the source region of the Yellow River," Joutnal of Geographical Science, vol. 64, no. 1, pp. 117-127, 2009.

[28] W. Yao, Z. Xu, and Y. Wang, "Analysis of runoff variation in Yellow River basin on the background of climate change," Meteorological and Environmental Science, vol. 2, pp. 1-6, 2009.

[29] A. W. Wood, L. R. Leung, V. Sridhar, and D. P. Lettenmaier, "Hydrologic implications of dynamical and statistical approaches to downscaling climate model outputs," Climatic Change, vol. 62, no. 1-3, pp. 189-216, 2004.

[30] L. E. Hay, M. P. Clark, R. L. Wilby et al., "Use of regional climate model output for hydrologic simulations," Journal of Hydrometeorology, vol. 3, no. 5, pp. 571-590, 2002. 

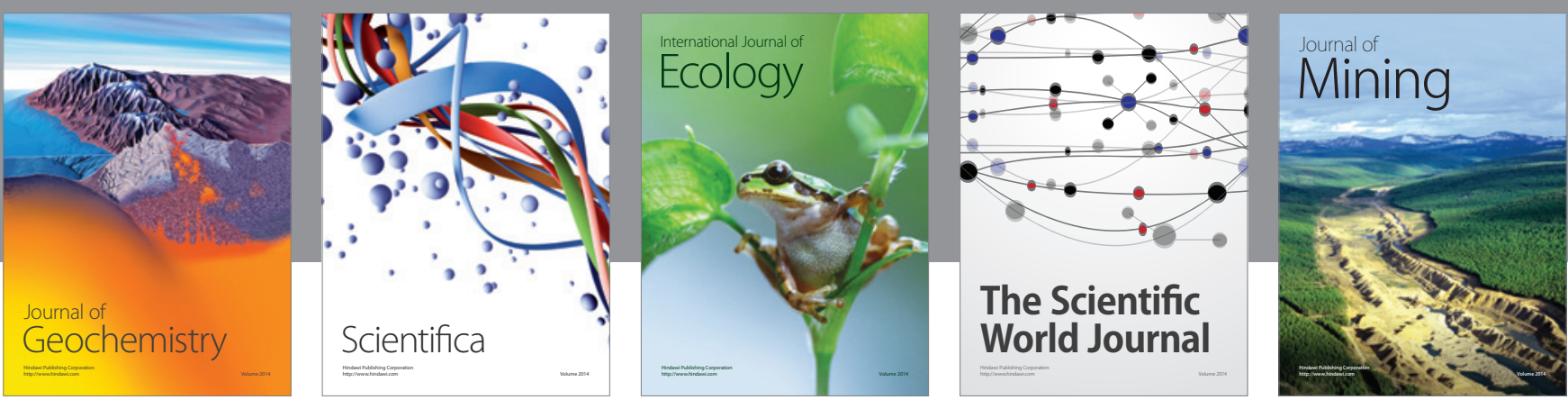

The Scientific World Journal
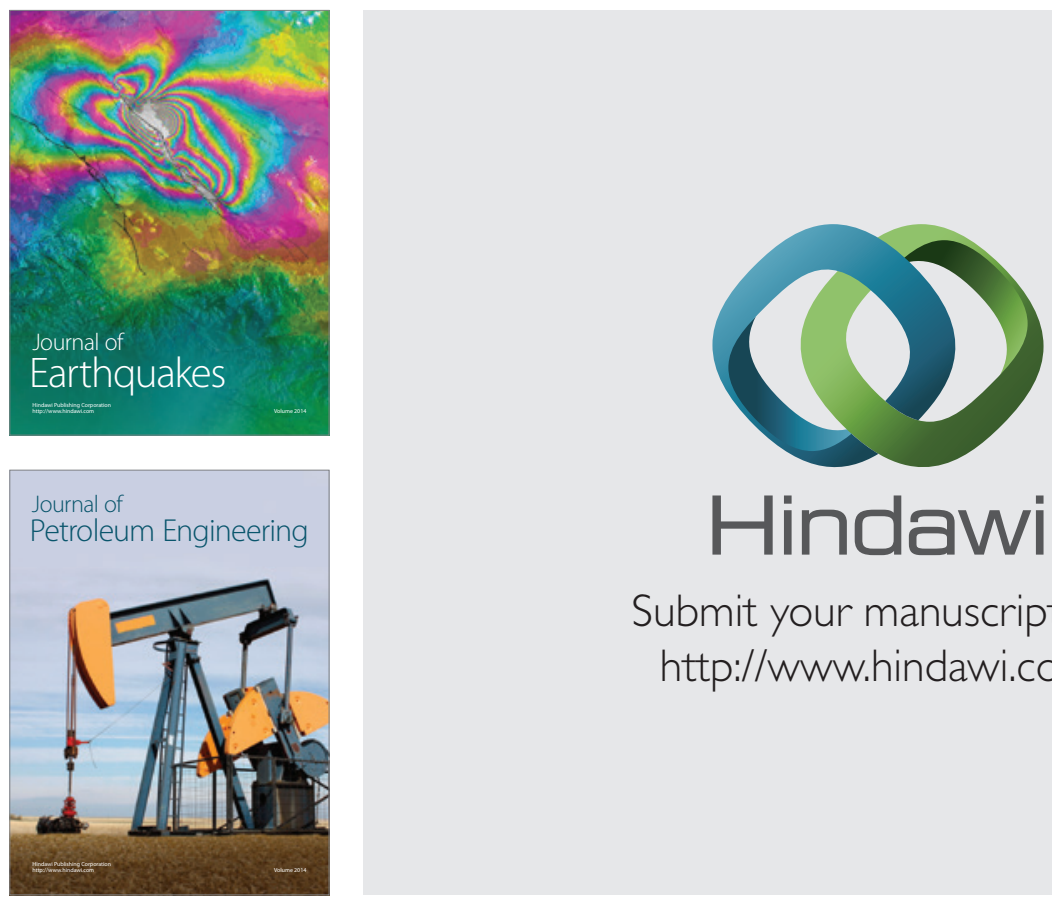

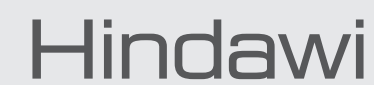

Submit your manuscripts at

http://www.hindawi.com
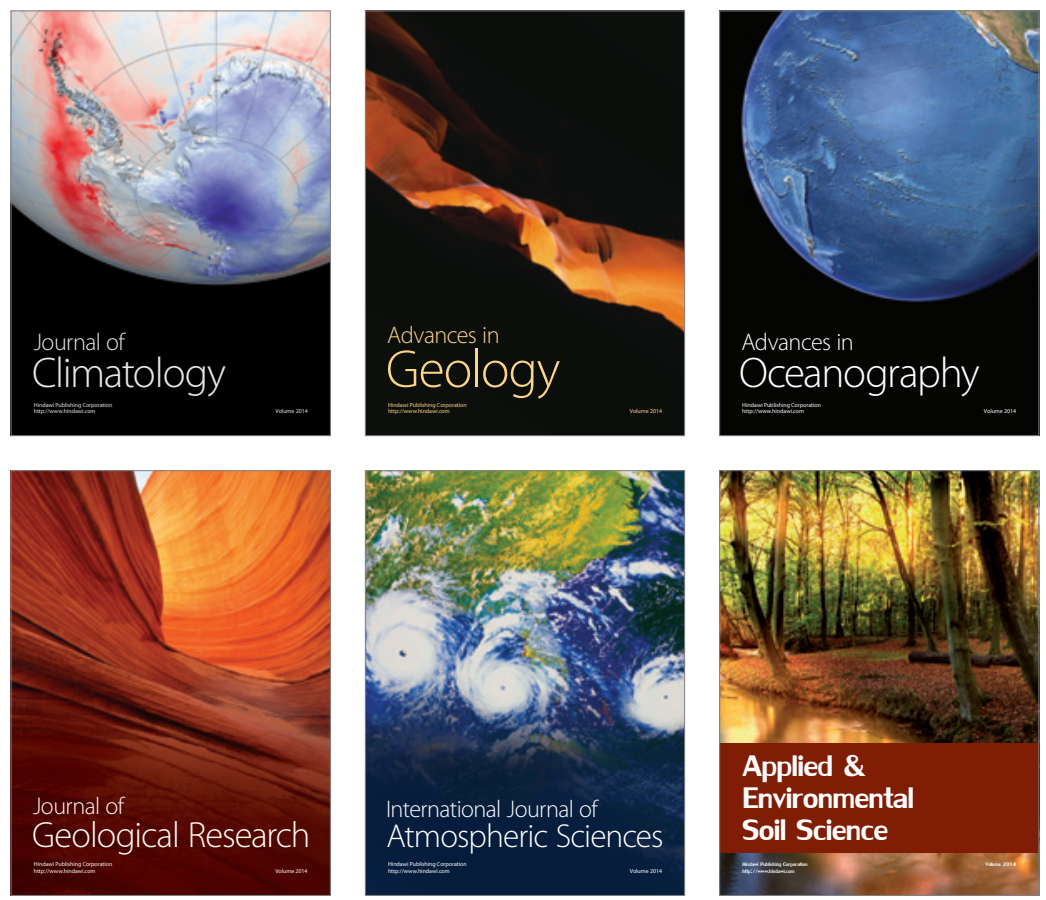
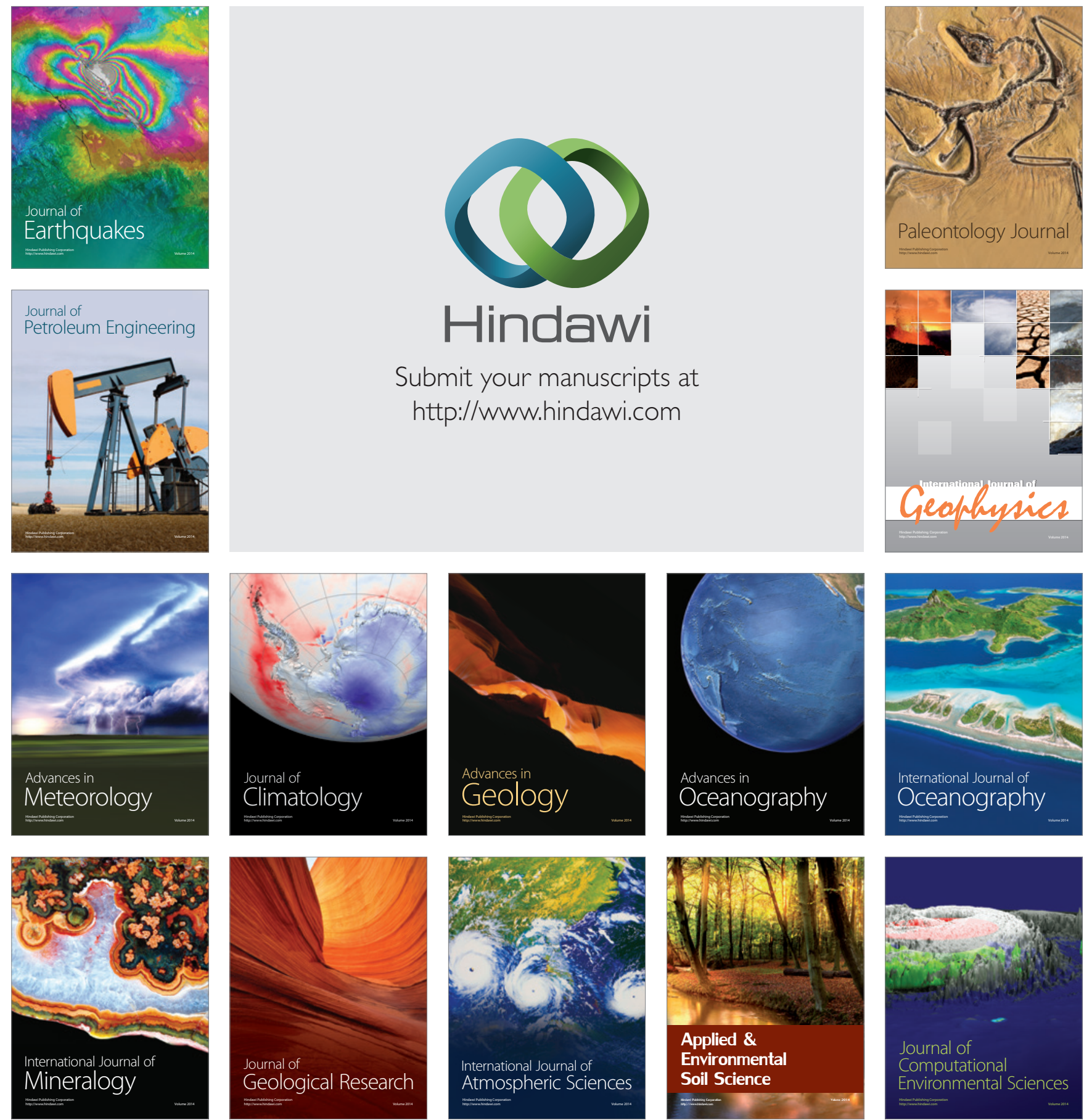